\author{
St ud i P hilos o p hi c a \\ Wr a t i s l a vi e n s i a \\ vol. XIII, fasc. 4 (2018) \\ DOI: $10.19195 / 1895-8001.13 .4 .6$
}

\begin{abstract}
MICHAE HERER
ORCID: 0000-0003-0808-7852

Uniwersytet Warszawski
\end{abstract}

\title{
Efekty (nie)równości
}

Znaki równości Michała Kozłowskiego to książka trudna do jednoznacznego zaklasyfikowania. Nie znajdziemy tu ani jasnej i wyraźnej definicji równości, ani argumentów na jej rzecz, co może zbić z tropu tradycyjnie nastawionego filozoficznego czytelnika. Osobiście akceptuję jednak wyrażony w Zakończeniu ${ }^{1}$ pogląd, że losy równości w niewielkim stopniu zależą od tego, czy intelektualiści, w szczególności filozofowie, zdołają przedstawić tego rodzaju argumenty. Co więcej, nie sądzę, by ich sformułowanie było w ogóle możliwe, przynajmniej jeśli miałyby mieć charakter ostateczny i niepodważalny. To, czy opowiadamy się raczej za równością, czy przeciw niej, jest kwestią praktycznego albo politycznego wyboru, którego nie da się w pełni uzasadnić na gruncie teorii. Wybór Kozłowskiego przebija wyraźnie z kart jego książki. Jak zauważa we Wstępie, obecny strukturalny kryzys kapitalizmu — w odróżnieniu od tego z początku lat siedemdziesiątych, na który odpowiedzią była polityka skrajnie antyrównościowa - sprzyja zresztą debatom nad możliwością bardziej egalitarnych stosunków społecznych². Zarazem „losy równości”, czyli konkretne, historyczne zmagania ludzi walczących o równość, próbujących ustanawiać jac na różnych poziomach i w rozmaitych warunkach, nie daja się łatwo sprowadzić do wspólnego mianownika. Dlatego słuszna wydaje się decyzja, by zamiast próbować na siłę zdefiniować, czym są stosunki egalitarne, podjąć raczej próbę ich „problematyzacji”. Ściśle rzecz biorąc, „problematyzacje”, czyli dyskursywne i pozadyskursywne praktyki „wprowadzające

\footnotetext{
${ }^{1}$ M. Kozłowski, Znaki równości. O społecznym konstruowaniu stosunków egalitarnych, Warszawa 2016, s. 221.

${ }^{2} \mathrm{~W}$ polu teorii ekonomicznych wystarczy wspomnieć prace Josepha Stiglitza i Thomasa Piketty'ego, przede wszystkim jednak wydaje się, że w szerokiej debacie publicznej mamy do czynienia z przekroczeniem neoliberalnego tabu, głoszącego, że nierówności stanowią konieczny i sprawiedliwy wynik ekonomicznej rywalizacji, gdzie „zawsze są wygrywający i przegrani”. Nawet pomijając często retoryczny charakter figury „1 procenta”, do powszechnej świadomości przebija się fakt, że wzrastające nierówności dochodów i poziomu życia mogą stanowić zagrożenie dla demokracji.
} 
jakąś rzecz w grę równości”3, są przedmiotem rozważań Kozłowskiego, które jednocześnie mają służyć dokonaniu „własnej autorskiej problematyzacji”4. Jest to, jak wiadomo, strategia z powodzeniem stosowana przez Michela Foucaulta ${ }^{5}$. Znaki równości napisane są właśnie w duchu Foucaultowskim, również w tym sensie, że łączą różne rodzaje analizy. Znajdziemy tu filozoficzną analizę pojęciową, elementy historii idei, krytykę ideologii, socjologiczno-historyczne studium przypadku, refleksje dotyczace polityki, ekonomii i kultury. Jest tak dlatego, że rozmaite bywały właśnie same historyczne formy problematyzacji równości. Skoro mowa o Foucaulcie, być może należało tylko bardziej uwyraźnić specyfikę owych równościowych problematyzacji na tle innych zmagań i walk w polu relacji władzy, zawsze polegajaccych na podważaniu wpisanych w te relacje asymetrii, rozkładu ,niższych i wyższych” pozycji w rozmaitych obszarach (praktyki symboliczne, ekonomia itp.).

Wewnętrzna heterogeniczność książki Kozłowskiego jest jej zaletą; odbija niejako heterogeniczność jej przedmiotu, umożliwia dostrzeżenie jego złożoności i dynamiki. Nie oznacza ona jednak, że zróżnicowany materiał historyczny nie został pojęciowo uporządkowany, że nie poddano go teoretycznej obróbce. Przeciwnie, Kozłowski wprowadza jasny podział na cztery typy albo figury, w które wpisują się jego zdaniem praktyki konstruowania stosunków egalitarnych. Jest to zarazem oś konstrukcyjna książki, owe cztery figury wyznaczają bowiem treść jej głównych rozdziałów (z wyjątkiem rozdziału pierwszego, poświęconego porównaniu teorii i praktyki równości w świecie greckim i rzymskim). Pytanie, na ile typologia ta jest wyczerpująca. Czy wszystkie znane nam historyczne problematyzacje równości wiążą się albo z „rządzeniem” za jej pomocą (1), albo z równościowym „wykluczającym uniwersalizmem” (2), albo ze „sprawczością zdominowanych”, którzy skutecznie domagają się równości (3), albo z jej odgórnym „ustanowieniem” (4)? Wydaje się, że rzeczywiście trudno o przykład, którego nie sposób przyporządkować do żadnej z tych figur, a nawet gdyby dało się podać takie przykłady, oznaczałoby to raczej tylko konieczność dodania kolejnej figury, bez podważania całej konstrukcji. Warto przy tym podkreślić, że każda z nich jest złożoną konstrukcją teoretyczną, odsłaniającą to, co w opisywanych praktykach i procesach najbardziej problematyczne, niejednoznaczne, czasem wręcz paradoksalne. Upodobanie Kozłowskiego do formułowania nieoczywistych hipotez i odrzucania komunałów (również tych naukowych czy filozoficznych) daje o sobie znać już w pierwszym rozdziale, w którym tak często idealizowana przez filozofów antyczna Grecja nie wytrzymuje, jeśli idzie o dynamikę dążeń równościowych, porównania z Rzymem:

Imperialny Rzym wygenerował rozmaite rozproszone tendencje egalitarne i uniwersalistyczne, pozbawione w zasadzie artykulacji politycznej i całościowego projektu politycznego. [...] Tymczasem ateńska demokracja, jakkolwiek na wskroś polityczna, wytworzyła jedynie mocarny mit demokratyczny $[\ldots]^{6}$.

\footnotetext{
${ }^{3}$ M. Kozłowski, Znaki równości..., s. 17.

4 Ibidem.

${ }^{5}$ Por. zwłaszcza Wprowadzenie do: M. Foucault, Użytek z przyjemności, [w:] idem, Historia seksualności, tłum. T. Komendant, Warszawa 1995, s. 143-171; problematyzacje zostają tam określone jako to, przez co „byt dany jest jako coś, co może i musi być pomyślane” - ibidem, s. 151.

${ }^{6}$ M. Kozłowski, Znaki równości..., s. 35, 36.
} 
Pozostaje on mitem nie tylko dlatego, że większość mieszkańców Aten była wykluczona ze wspólnoty politycznej, ale także ze względu na fakt, iż mowa o „projekcie równości politycznej pozbawionej równości społecznej lub wręcz przeciwstawionej równości w świecie społecznym"7. Ta ocena ateńskiej demokracji pozostaje w bezpośrednim związku z pewnym teoretycznym założeniem poczynionym we Wstępie. Problematyzacje równości dokonują się mianowicie zawsze w związku z dystrybucją trzech rodzajów zasobów albo „kapitału” (w sensie Bourdieu): prestiżu, władzy i kapitału ekonomicznego, przy czym — zgodnie z zasadą konwersji albo wymiany — za „przekształcenia równościowe” uznać można „tylko te, które oznaczają bardziej egalitarną dystrybucję więcej niż jednego z tych zasobów"8. Choć z tekstu nie wynika jednoznacznie, za jakiego rodzaju kapitał uznaje Kozłowski samą przynależność do wspólnoty politycznej (najbliżej byłoby jej chyba do „władzy"), jest jasne, że tylko w ograniczonym stopniu polega ona wymianie na kapitał społeczny i ekonomiczny. Wydaje się to ciekawą strategią odczarowania greckiego mitu; szkoda, że w książce została ona jedynie zarysowana.

Zamiast streszczenia czterech głównych rozdziałów książki Kozłowskiego wskażę wątki, które wydają mi się szczególnie ciekawe i oryginalne, a także pewne teoretyczne trudności, z jakimi trzeba się zmierzyć, przyjmując zaproponowaną przez niego perspektywę.

W rozdziale drugim na uwage zasługuje przede wszystkim sama figura ,rządzenia równością". Choć koncept ten powstał pod wpływem analiz Foucaulta dotyczących wolności jako korelatu albo wręcz wytworu pewnego rodzaju władzy, nie mamy tu do czynienia z prostą aplikacją Foucaultowskiego schematu. Foucault pisał:

Jeśli używam tego słowa [wolność - M.H.], to dlatego, że praktyka rządzenia, która się tu wyłania, nie ogranicza się do respektowania, gwarantowania takich czy innych swobód. Na głębszym poziomie wolność jest raczej tym, co praktyka ta konsumuje. Jest tak dlatego, że może ona funkcjonować tylko pod warunkiem istnienia pewnych swobód: wolności rynku, wolności kupna i sprzedaży, swobodnego korzystania z prawa własności, wolności dyskusji albo wolności słowa itd. Nowa sztuka rządzenia potrzebuje więc wolności, konsumuje ją. Co oznacza, że wciąż domaga się jej wytwarzania i organizowania. Nowa sztuka rządzenia jawi się zatem jako zarządzanie wolnością, nie w sensie imperatywu: „bądź wolny”, od razu wikłającego się zresztą w sprzeczność. Formułą liberalizmu nie jest „bądź wolny”. Liberalizm powiada jedynie: wytworzę cię jako wolnego. Sprawię, że będziesz miał niejako swobodę bycia wolnym. O tyle też, skoro liberalizm opiera się nie tyle na nakazie wolności, ile na zarządzaniu nią i kształtowaniu warunków, pod jakimi można w ogóle być wolnym, widać wyraźnie, jak w samym centrum praktyki liberalnej zawiązuje się problematyczna i zawsze zmienna, mobilna relacja między produkcją wolności a tym, kto — produkując ją — ryzykuje, że ją ograniczy albo zniszczy. Liberalizm, tak jak ja go rozumiem, liberalizm, który można by określić jako nową, ukształtowaną w XVIII wieku sztukę rządzenia, zakłada ów podstawowy stosunek produkcji wolności do jej destrukcji ${ }^{9}$.

Kozłowski w przekonujący sposób, i bodaj wyraźniej niż uczynił to autor Nadzorować i karać w stosunku do wolności, łączy równość jako narzędzie rządzenia z funkcjonowaniem instytucji dyscyplinarnych. W jego ujęciu instytucją modelo-

7 Ibidem, s. 34.

8 Ibidem, s. 24.

${ }^{9}$ Por. M. Foucault, Narodziny biopolityki. Wyktady w Collège de France. 1978-1979, tłum. M. Herer, Warszawa 2011, zwł. wykład z 24 stycznia 1979 (s. 87). 
wą okazuje się wszelako nie więzienie, lecz nowa, pod pewnymi względami dużo bardziej demokratyczna i egalitarna niż w przeszłości, wczesnonowożytna armia. W ten sposób udaje mu się uchwycić podstawową ambiwalencję urządzeń dyscyplinarnych albo, jak sam to określa, „logikę ceny, jaką władza musi płacić za skuteczne rządzenie"10. Władza nie przeciwstawia się a priori równości, czasem posługuje się nią albo nią zarządza, przez co instrumentalizowane przez nią stosunki egalitarne nie stają się przecież czymś nierzeczywistym (wojna faktycznie bywała, jak pisze Kozłowski, „największym stymulatorem społecznej mobilności”11).

Jednocześnie — i jest to aspekt, który należałoby chyba ukazać wyraźniej — równość będąca technologia rządzenia nigdy nie przekracza jednak pewnych, zazwyczaj dość wąskich, granic. Jest realna, ale z zasady właśnie ograniczona. Niekiedy tak bardzo, że owa realność zdaje się asymptotycznie dążyć do zera. Najlepiej widać to na przykładzie „równości szans”. W książce słusznie wskazuje się na nią jako na podstawową figurę równości w neoliberalizmie; pytanie brzmi jednak, na ile jest ona rzeczywistym korelatem pewnej technologii rządzenia, na ile zaś pełni funkcję ideologicznej przesłony, za którą skrywają się realne nierówności. Jak zauważa Kozłowski:

gdyby poważnie przyjrzeć się warunkom społecznym, które musiałyby być spełnione, aby szanse jednostek w punkcie wyjścia ekonomicznej lub symbolicznej rywalizacji były rzeczywiście równe, to okaże się, że kapitalistyczne społeczeństwo nie jest w stanie ich spełnić ze względów strukturalnych ${ }^{12}$.

W tej sytuacji „równość szans to tyle, co prawo do uczestnictwa w grze nierówności na pewnych zasadach uznanych za prawomocne i sprawiedliwe"13. Wydaje się, że z perspektywy przyjętej przez Kozłowskiego dałoby się odeprzeć zarzut, że równość szans jest jedynie pozorem, a nie realną figurą równości; do jego wywodu trzeba by jednak wprowadzić dodatkowe kategorie i rozróżnienia — rzecz jasna inne niż tradycyjne rozróżnienie pozoru i rzeczywistości (albo istoty). Skoro tak zwana równość szans nie oznacza - i z powodów strukturalnych nie może oznaczać — równości pozycji, z jakich startują jednostki rywalizujące o rozmaite typy kapitału, to czym faktycznie jest? Na czym polega jej specyficzna realność? Czy chodzi wyłącznie o realność pewnego - ideologicznego w tradycyjnym znaczeniu tego słowa - dyskursu, który przekonuje nierównych rządzonych, że są równi, aby spacyfikować ich potencjalny bunt? Równość jako technologia rządzenia wymaga chyba czegoś więcej — wymaga, mówiąc po Foucaultowsku, wytwarzania ludzi jako równych, ale tylko w pewnym sensie i pod pewnym względem. W wypadku równości szans chodziłoby może o aspekt formalno-prawny, o te same reguły dla wszystkich uczestników ekonomicznej gry, w odróżnieniu od nierówności — by tak rzec - efektywnej, czyli powstającej w efekcie, w rezultacie rywalizacji. Choć z drugiej strony: czy owe reguły kiedykolwiek były tak neutralne i egalitarne, jak utrzymują obrońcy (neo)liberalizmu?

\footnotetext{
${ }^{10}$ M. Kozłowski, Znaki równości..., s. 58.

11 Ibidem, s. 55.

12 Ibidem, s. 89.

13 Ibidem, s. 38.
} 
W związku z prezentowaną w rozdziale trzecim figura ,,wykluczającego uniwersalizmu" nasuwa się nieco podobne pytanie. Kozłowski podąża tu tropem autorów demaskujących partykularny charakter wszelkiego rzekomo uniwersalistycznego dyskursu. Może to być uniwersalizm cywilizacji Zachodu, społeczeństwa obywatelskiego albo męskiego podmiotu — za każdym razem pojawia się podejrzenie, że to, co przedstawia się jako powszechnie obowiązującą (i w tym sensie zrównujaccą) zasadę, stanowi tylko arbitralnie i zazwyczaj przemocowo narzuconą siatkę wyróżnionych pojęć bądź praktyk. Na tym polega opisywany przez Edwarda Saida orientalizm, którego filarem jest

uznanie tego, co partykularne (Zachodu oraz jego kultury, religii, prawa i obyczaju) za uniwersalne (prawdziwie ludzkie, rozumne, etyczne), a tego, co wschodnie, za egzotyczne (mroczne, zwierzęce, mętne i przewrotne $)^{14}$.

Podobny mechanizm rządzi logiką społeczeństwa obywatelskiego, demaskowanego przez Marksa jako „burżuazyjne”, oraz ujawnianym przez studia feministyczne dyskursem „fallocentrycznym” (nawiasem mówiąc, do opisu owego szczególnego „podstawienia” partykularności w miejsce tego, co uniwersalne, do zrozumienia jego konstytutywnej, strukturalnej roli w tworzeniu każ d ej uniwersalności z filozoficznego punktu widzenia najlepsza wydaje się dekonstrukcyjna strategia Derridy, do której Kozłowski niemal się nie odwołuje). Z jakiego punktu widzenia można wszelako określić ten rodzaj uniwersalizmu jako „fałszywy”? I na czym polega ta fałszywość? Czy tylko na jego ograniczeniu? Wtedy wystarczyłoby po prostu rozszerzyć jego zakres — włączyć wykluczonych (przedstawicieli innych kultur, proletariat, kobiety), nie zmieniajac nic w samej uniwersalnej idei. Czy byłoby to jednak wystarczające? Czy, mówiąc obrazowo, chodzi o to, by proletariusz stał się burżua? Ale czy z drugiej strony można po prostu porzucić uniwersalizm, nawet jeśli ów fałsz stanowi warunek jego możliwości? Czy sprawa równości nie musiałaby na tym ucierpieć? W tekście pytania te są zasygnalizowane i choć odpowiedź na nie jest arcytrudna, zabrakło może nieco uporu i konsekwencji w ich rozważaniu.

Szczególnie ciekawe są analizy Kozłowskiego dotyczące trzeciej, omawianej w kolejnym rozdziale figury równości, czyli ,sprawczości zdominowanych”. Jest to problematyka podejmowana między innymi przez autorów spod znaku włoskiego operaizmu, jednak w odróżnieniu choćby od Antonio Negriego, który dokonujacc odwrócenia tradycyjnej perspektywy, przyznaje zdominowanym źródłową sprawczość, poczynania władzy uznaje zaś za czysto reaktywne, Michał Kozłowski w punkcie wyjścia kładzie nacisk na to, że realna nierówność (i związany z nią podporządkowany status jednostek czy grup) podlega uwewnętrznieniu. Podmiotowość zdominowanych konstytuuje się w dużej mierze właśnie w relacji nierówności, przez co podmiotowy akt zakwestionowania owej relacji nabiera charakteru paradoksalnego: „czy wyzwolona powinna zostać tożsamość zdominowanych, czy też zdominowani wyzwolić się mają od własnej tożsamości?"15. O wartości podejścia, które proponuje Kozłowski, stanowi jego niechęć do poszukiwania jednoznacznych rozwiązań tego rodzaju dylematów. W duchu przenikającej cały jego tekst teore-

\footnotetext{
14 Ibidem, s. 118.

${ }^{15}$ Ibidem, s. 135.
} 
tycznej ostrożności zdaje się on twierdzić, że istnieje z a rów no pewna sprawczość po stronie zdominowanych (pomimo uwewnętrznienia przez nich podrzędnego statusu oraz ograniczonego zasobu materialnych i symbolicznych narzędzi, za pomoca których mogą domagać się równości i ją ustanawiać), jak i pewna (nawet dość znaczna) inercja nieegalitarnych struktur czy układów sił. Z drugiej zaś strony, nie ma ani absolutnej sprawczości po stronie oporu, ani władzy absolutnie spójnej i skonsolidowanej. „Jedyne, czego dowieść może historyczna sprawczość zdominowanych, to względnej nieszczelności wszelkich systemów dominacji i ich sposobów historycznej reprodukcji"16. W tej sytuacji prosiłoby się jednak o próbę „mieszanej” analizy tej figury oraz figury pierwszej. Względny charakter sprawczości zdominowanych podmiotów często wszak oznacza, że są oni — jako działający — jednocześnie przedmiotami jakiegoś rządzenia czy zarządzania. Czy można więc mówić o czymś takim jak ,zarządzanie sprawczością zdominowanych”? Uwaga ta odnosi się zresztą do całej konstrukcji książki, w której poszczególne figury równości są analizowane raczej osobno i niezależnie, podczas gdy w rzeczywistości tworzą właśnie złożone mieszaniny.

$\mathrm{Na}$ ostatni, piąty rozdział składają się trzy studia przypadków tego, co nazywa się tu „równością przez ustanowienie”. Motywem przewodnim jest, ponownie, paradoks, polegający tym razem na tym, że w określonych warunkach społecznych i ekonomicznych równość bywa też ustanawiana odgórnie, a więc niejako na fundamencie nierówności. Klasykiem takiego autorytarnego egalitaryzmu jest Lenin (pierwsze studium), Kozłowski przywołuje jednak w tym kontekście również postać B.R. Ambedkara (studium drugie), a także historię Krystyny W., kobiety pracującej w kopalni we wczesnych latach pięćdziesiątych, w okresie przyspieszonej industrializacji, kiedy to władze PRL zdecydowały się na „ograniczony, lecz rzeczywisty projekt równościowych stosunków między mężczyznami i kobietami”"17 (studium trzecie). I znów, pytanie - które analizy te wprawdzie prowokują, nie dostarczają na nie jednak wyczerpującej odpowiedzi - dotyczy rodzaju owej realności. Odgórnie ustanowiona równość, nawet jeśli ograniczona, jest wszak realna — inaczej niż w wypadku „równości szans” Kozłowski konsekwentnie trzyma się tu ostrożnego, antymetafizycznego podejścia i nie sugeruje przeciwstawienia równości prawdziwej i pozornej — ale czy jest dziełem przypadku, że rzadko kiedy bywa trwała, że ta sama władza, która zaprowadza ją odgórnym dekretem, prędzej czy później (raczej prędzej) wycofuje się z egalitarnej polityki? Wydaje się, że właśnie quasi-pozytywistyczna metoda stosowana przez Kozłowskiego powinna umożliwiać rozważanie rodzaju tego rodzaju kwestii. Być może znów przydatne mogłoby się przy tym okazać odwołanie do Foucaulta, w tym przypadku do przejścia od rozwijanej przez niego w latach siedemdziesiątych koncepcji władzy wytwarzającej ujarzmiony podmiot do późniejszych opisów praktyk i technik Siebie. Przejścia tego nie należy, jak wiadomo, interpretować jako odwrotu od absolutnego „determinizmu” władzy do równie dogmatycznej koncepcji podmiotowej autopoiesis. Sprawczość nie przynależy w sposób pełny i absolutny ani do żadnej

16 Ibidem, s. 179.

17 Ibidem, s. 213. 
ze stron relacji władzy, ani nawet do „samej relacji”, kosztem jej członów. Wszystko jest raczej kwestią okoliczności i proporcji. Te zaś sprawiają, że efekt - czyli pewna forma podmiotowości albo, jak u Kozłowskiego, równość rozumiana jako konkretny egalitarny stosunek społeczny — ma, na przykład, mniejszą lub większą trwałość. Czy można powiedzieć, że efekty te różnią się także jakościowo? Nie, jeśli miałoby to oznaczać, że w jednym z nich (efekty odgórnego ustanowienia równości) są bardziej rzeczywiste albo prawdziwe od innych (od równości wywalczonej w większym stopniu przez samych zdominowanych). Rzecz jednak w tym, że metafizyczna różnica między pozorem a prawdą często przesłania inne, nie pozwalając na ich problematyzację na gruncie teorii. Co więcej, te inne różnice mogą być dużo ciekawsze z filozoficznego, a już na pewno z politycznego punktu widzenia. To, czy dane zjawisko stanowi efekt odgórnego ustanowienia albo dekretu rządzących, czy też, przeciwnie, wynika z oddolnej praktyki rządzonych, musi przecież w jakiś sposób wpływać na jego jakościową charakterystykę, nawet jeśli w obu przypadkach jest ono tak samo prawdziwe czy realne. I właśnie te jakości mają znaczenie polityczne, a w każdym razie przekładają się na polityczną i historyczną dynamikę owego zjawiska, czy będzie to Foucaultowska podmiotowość, czy efekty równościowe w rozumieniu Kozłowskiego. 